\title{
HPV TYPING AS A SCREENING PROGRAM FOR PREVENTION AND EARLY DETECTION OF CERVICAL CANCER IN DIFFERENT MONTENEGRO REGIONS
}

\author{
Azra Lukač $\check{1}^{1}$ Nenad Šulović , Sonja Smiljićc ${ }^{3}$, Aleksandra N. Ilić ${ }^{4}$ and Mirza Šašić ${ }^{5}$ \\ ${ }^{1}$ Community Health Center, Rožaje, Montenegro; ${ }^{2}$ Department of Gynecology and Obstetrics, \\ Faculty of Medicine, University of Prishtina, Kosovska Mitrovica, Serbia; \\ ${ }^{3}$ Department of Psychology, Faculty of Medicine, University of Prishtina, Kosovska Mitrovica, Serbia; \\ ${ }^{4}$ Institute for Preventive Medicine, Faculty of Medicine, University of Prishtina, Kosovska Mitrovica, Serbia; \\ ${ }^{5}$ Department of Obstetrics and Gynecology, State Hospital, Novi Pazar, Serbia
}

SUMMARY - The objective of our research was to compare the results of human papillomavirus (HPV) typing and occurrence of the most important risk factors for cervical cancer obtained in the towns of northern, central and southern regions of Montenegro, in subjects between 30 and 35 years of age, in accordance with the new screening program introduced by the Ministry of Health of Montenegro in 2018. The study included 400 patients aged 30-35 years from Rožaje, Berane, Budva and Podgorica, 100 from each town, who underwent HPV typing in accordance with the latest screening program for early detection and prevention of cervical cancer, approved by the Ministry of Health of Montenegro in 2018. The material was obtained and sampled at the Health Clinics in Rožaje, Berane, Podgorica and Budva. Specially designed brushes were used to take swabs from the cervices, which were then sampled in separate collection tubes that contained a liquid transport medium. The samples were then sent for further analysis to the Institute of Public Health of Montenegro where HPV typing was performed using the real-time polymerase chain reaction method. The results were encrypted and obtained electronically. The data obtained from the questionnaires each subject filled out in accordance with this program were analyzed and the subjects willingly agreed to partake in the screening program. Nearly one-quarter of subjects had a positive HPV finding. The group of HPV positive women included significantly more women from Podgorica $\left(\chi^{2}\right.$-test $\left.=26.455, p<0.001\right)$, women with very good living conditions $\left(\chi^{2}\right.$-test $\left.=12.264, p<0.001\right)$, women who smoked cigarettes $\left(\chi^{2}\right.$-test $=5.074$, $\mathrm{p}=0.024)$, women who had the first sexual intercourse between the ages of 17 and $20\left(\chi^{2}\right.$-test $=5.874$, $\mathrm{p}=0.015)$, and women who did not have permanent partners $\left(\chi^{2}\right.$-test $\left.=6.061, \mathrm{p}=0.014\right)$. Among the observed socio-demographic characteristics and sexual behaviors of our subjects that proved to be non-significant variables in their HPV statuses we excluded the length of smoking habit $\left(\chi^{2}\right.$-test $=0.638$, $\mathrm{p}=0.424)$ and protected sexual intercourse $\left(\chi^{2}\right.$-test $\left.=2.628, \mathrm{p}=0.105\right)$. By implementing the screening program and HPV typing, we came to a conclusion that the problem of cervical cancer could be solved or at least mitigated by raising awareness of the causes and incidence of cervical cancer, as well as by being well informed on its curability, predictability and protection during intercourse, which would contribute to positive changes.

Key words: HPV infection; Risk factors; Cervical cancer

\section{Introduction}

Systemized examinations have led to a decrease in cervical cancer mortality in the last fifty years. How-
Correspondence to: Azra Lukač, Community Health Center, Rožaje, Montenegro

E-mail: azra430@hotmail.com

Received October 9, 2019, accepted January 16, 2020 
ever, many developing countries, including Montenegro, have not benefited much from the examination program, and in some developed countries there has been an increase of cervical cancer occurrence. Human papillomavirus (HPV) has been recognized as the primary cause of the disease and significant coexistent factors have also been identified. These are crucial steps towards developing effective programs for the prevention and successful treatment of cervical cancer, which can be adapted to different countries. It is important to note that in Montenegro, cervical cancer affects about 100 women annually, $30-40$ of which die ${ }^{1,2}$. Given that Montenegro is a country with about 630,000 inhabitants, such data along with the fact that cervical cancer is the second most common disease in women in Montenegro, right after breast cancer, are worrying. Cervical cancer in developing countries is so frequent due to the inaccessibility of screening tests that would identify or predict this type of cancer (HPV testing, etc.) and enable treatment or prevention. It is estimated that approximately $5 \%$ of women in developing countries undergo tests for cervical cancer, whereas in developed countries over $40 \%$ of women are regularly tested $^{3}$. In $99 \%$ of cases, women with cervical cancer tested positive for HPV DNA and cervical dysplasia related to it, indicating not only that is HPV one of the main causes of cervical cancer, but that this type of cancer can be detected on time.

Unfortunately, in most developing countries, the approach to cervical cancer treatment is very aggressive, usually through performing complicated and risky surgeries or hysterectomy, which leads to numerous side effects and complications. Ambulatory surgeries, such as cryotherapy, laser surgery and the like, are most effective, but, unfortunately, there is little probability of implementing them in developing countries.

Since January 2018, a new screening program for early detection and prevention of cervical cancer in Montenegro has created conditions for HPV DNA test, which is now conducted in all towns covering patients born between 1983 and 1988.

The objective of our research was to obtain the results of HPV typing. We analyzed the incidence of the most important risk factors for cervical cancer and their correlation with HPV infection in female patients between the ages of 30 and 35, in the towns of northern, central and southern regions of Montenegro, in accordance with the first screening program for the prevention and early detection of cervical cancer ever conducted in Montenegro, that was also approved by the Ministry of Health of Montenegro.

\section{Materials and Methods}

This prospective study was conducted in the towns of northern, central and southern regions of Montenegro. The study lasted from January 2018 until January 2019 and included a planned population of 400 female subjects (100 subjects from the towns of Berane, Rožaje, Budva and Podgorica), born between 1983 and 1988, selected by the Health Insurance Fund of Montenegro in accordance with the regulations of screening program for the prevention and early detection of cervical cancer approved by the Ministry of Health of Montenegro. The material was obtained and sampled at the Health Clinics in Rožaje, Berane, Podgorica and Budva. Specially designed brushes were used to take swabs from the cervices, which were then sampled in separate collection tubes that contained a liquid transport medium. The samples were then sent for further analysis to the Institute of Public Health of Montenegro where HPV typing was performed, using the real-time polymerase chain reaction (PCR) method. The results were encrypted and obtained electronically. The data obtained from the questionnaires each subject filled out in accordance with this program were analyzed and the subjects willingly agreed to partake in the screening program.

\section{Statistical analysis}

For the analysis of primary data, we used descriptive statistical methods and statistical hypothesis testing. We used relative numbers as the descriptive statistical method. The $\chi^{2}$-test was used to analyze differences between frequency values. Statistical hypotheses were tested at the level of statistical significance of 0.05 . For the purpose of statistical data analysis, SPSS Statistics 22 software package was used.

\section{Results}

Positive HPV findings were recorded in 122 subjects ( $28 \%$ of the total study population), whereas 288 (72\%) subjects had negative results. As regards the socio-demographic characteristics and sexual behavior of the subjects, we considered the place of residence 
Table 1. Socio-demographic characteristics and sexual behavior of subjects affecting the human papillomavirus (HPV) status

\begin{tabular}{|c|c|c|c|}
\hline \multirow{3}{*}{ Variable } & \multicolumn{2}{|c|}{$\mathrm{HPV}$} & \multirow{3}{*}{$\mathrm{p}$} \\
\hline & \multirow{2}{*}{\begin{tabular}{|l} 
Negative \\
$\mathrm{n}(\%)$ \\
\end{tabular}} & \multirow{2}{*}{\begin{tabular}{|l} 
Positive \\
$\mathrm{n}(\%)$
\end{tabular}} & \\
\hline & & & \\
\hline & $288(72.0)$ & $112(28.0)$ & \\
\hline \multicolumn{4}{|l|}{ Residence } \\
\hline Northern region & $168(58.3)$ & $32(28.6)$ & \multirow{3}{*}{$<0.001^{*}$} \\
\hline Central region & $52(18.1)$ & $48(42.9)$ & \\
\hline Southern region & $68(23.6)$ & $32(28.6)$ & \\
\hline \multicolumn{4}{|l|}{ Living conditions } \\
\hline Good & $136(47.2)$ & $29(25.9)$ & \multirow{3}{*}{$<0.001^{*}$} \\
\hline Very good & $51(17.7)$ & $38(33.9)$ & \\
\hline Excellent & $101(35.1)$ & $45(40.2)$ & \\
\hline \multicolumn{4}{|l|}{ Smoker } \\
\hline No & $82(63.2)$ & $57(50.9)$ & \multirow{2}{*}{$0.024^{*}$} \\
\hline Yes & $106(36.8)$ & $55(49.1)$ & \\
\hline \multicolumn{4}{|l|}{$\begin{array}{l}\text { Length of smoking } \\
\text { habit }\end{array}$} \\
\hline$<10$ years & $71(66.4)$ & $33(60.0)$ & \multirow{2}{*}{0.424} \\
\hline$>10$ years & $36(33.6)$ & $22(40.0)$ & \\
\hline \multicolumn{4}{|l|}{$\begin{array}{l}\text { Age at first sexual } \\
\text { intercourse (years) }\end{array}$} \\
\hline$<16$ & $20(6.9)$ & $15(13.4)$ & \multirow{4}{*}{$0.002^{*}$} \\
\hline $17-20$ & $136(47.2)$ & $68(60.7)$ & \\
\hline $21-24$ & $100(34.7)$ & $24(21.4)$ & \\
\hline$>25$ & $32(11.1)$ & $5(4.5)$ & \\
\hline \multicolumn{4}{|l|}{ Permanent partner } \\
\hline No & $42(14.6)$ & $28(25.0)$ & \multirow{2}{*}{$0.014^{*}$} \\
\hline Yes & $246(85.4)$ & $84(75.0)$ & \\
\hline \multicolumn{4}{|l|}{$\begin{array}{l}\text { Protected sexual } \\
\text { intercourse }\end{array}$} \\
\hline No & $251(87.2)$ & $104(92.9)$ & \multirow{2}{*}{0.105} \\
\hline Yes & $37(12.8)$ & $8(7.1)$ & \\
\hline
\end{tabular}

$\left(\chi^{2}\right.$-test $\left.=42.956, \mathrm{p}<0.001\right)$, living conditions $\left(\chi^{2}\right.$-test $=$ 19.006, $\mathrm{p}<0.001)$, smoking habit $\left(\chi^{2}\right.$-test $=5.074, \mathrm{p}=$ $0.024)$, first sexual intercourse $\left(\chi^{2}\right.$-test $=15,159, \mathrm{p}=$ $0.002)$, and having a permanent partner $\left(\chi^{2}\right.$-test $=6.061$, $\mathrm{p}=0.014)$ as significant variables affecting the HPV status.

In the group of women who were HPV positive, there were significantly more women from Podgorica $\left(\chi^{2}\right.$-test $\left.=26.455, \mathrm{p}<0.001\right)$, women with very good liv- ing conditions $\left(\chi^{2}\right.$-test $\left.=12.264, \mathrm{p}<0.001\right)$, women who smoked cigarettes $\left(\chi^{2}\right.$-test $\left.=5.074, \mathrm{p}=0.024\right)$, women who had their first sexual intercourse between the ages of 17 and $20\left(\chi^{2}\right.$-test $\left.=5.874, p=0.015\right)$, and women without permanent partners $\left(\chi^{2}\right.$-test $\left.=6.061, p=0.014\right)$.

As regards the socio-demographic characteristics and sexual behavior of the subjects, we found that the length of smoking habit $\left(\chi^{2}\right.$-test $\left.=0.638, p=0.424\right)$ and protected sexual intercourse $\left(\chi^{2}\right.$-test $\left.=2.628, \mathrm{p}=0.105\right)$ were not significant variables affecting the HPV status.

The gynecologic characteristics and associated diseases that significantly affected the HPV status were the presence of anemia $\left(\chi^{2}\right.$-test $\left.=8.974, p=0.003\right)$, number of childbirths $\left(\chi^{2}\right.$-test $\left.=13.537, p=0.004\right)$, menarche $(\mathrm{t}=2.283, \mathrm{p}=0.023)$, abortion $\left(\chi^{2}\right.$-test $\left.=8.921, \mathrm{p}=0.003\right)$, and usage of intrauterine devices (IUDs) $\left(\chi^{2}\right.$-test= 6.772, $\mathrm{p}=0.009$ ).

In the group of women who were HPV positive, there were significantly more women with anemia $\left(\chi^{2}-\right.$ test $=8.974, \mathrm{p}=0.003)$, nulliparous women $\left(\chi^{2}\right.$-test $=$ 9.902, $\mathrm{p}=0.002)$, women with early menarche $(\mathrm{t}=2.283$, $\mathrm{p}=0.023)$, women who did not have abortions $\left(\chi^{2}-\right.$ test $=8.921, \mathrm{p}=0.003)$ and women who never used IUDs $\left(\chi^{2}\right.$-test $\left.=6.772, p=0.009\right)$.

The gynecologic characteristics and associated diseases that did not have a statistically significant effect on the HPV status were systemic diseases $\left(\chi^{2}\right.$-test= 0.087, $\mathrm{p}=0.768)$, impaired immunity and previous treatment of systemic diseases $\left(\chi^{2}\right.$-test $\left.=2.824, \mathrm{p}=0.093\right)$, malignant gynecologic diseases in close relatives $\left(\chi^{2}-\right.$ test $=3.018, p=0.082)$, age of the affected relative $(p=$ $0.653)$, usage of oral contraceptives $\left(\chi^{2}\right.$-test $=1.235$, $\mathrm{p}=0.266)$, and current usage of IUDs $\left(\chi^{2}\right.$-test $=1.924$, $\mathrm{p}=0.165)$.

The results of univariate logistic regression model analysis showed that the variables associated with an increased risk of HPV infection were the place of residence [central region $(B=1.13, p=0.002)$ compared to the northern region taken as a reference category] and anemia $(\mathrm{B}=1.91, \mathrm{p}=0.012)$, while menarche $(\mathrm{B}=-0.22$, $\mathrm{p}=0.017)$ and abortion $(\mathrm{B}=-0.69, \mathrm{p}=0.043)$ had reduced the risk of HPV infection.

The multivariate logistic regression model included 4 predictors and the entire model was statistically significant $\left(\chi^{2}\right.$-test $\left.=54.856, \mathrm{p}<0.001\right)$. According to the multivariate logistic regression model, the statistically significant predictors associated with an increased risk of HPV infection were the place of residence [central 
Table 2. Distribution of gynecologic characteristics and associated diseases that affect the human papillomavirus (HPV) status

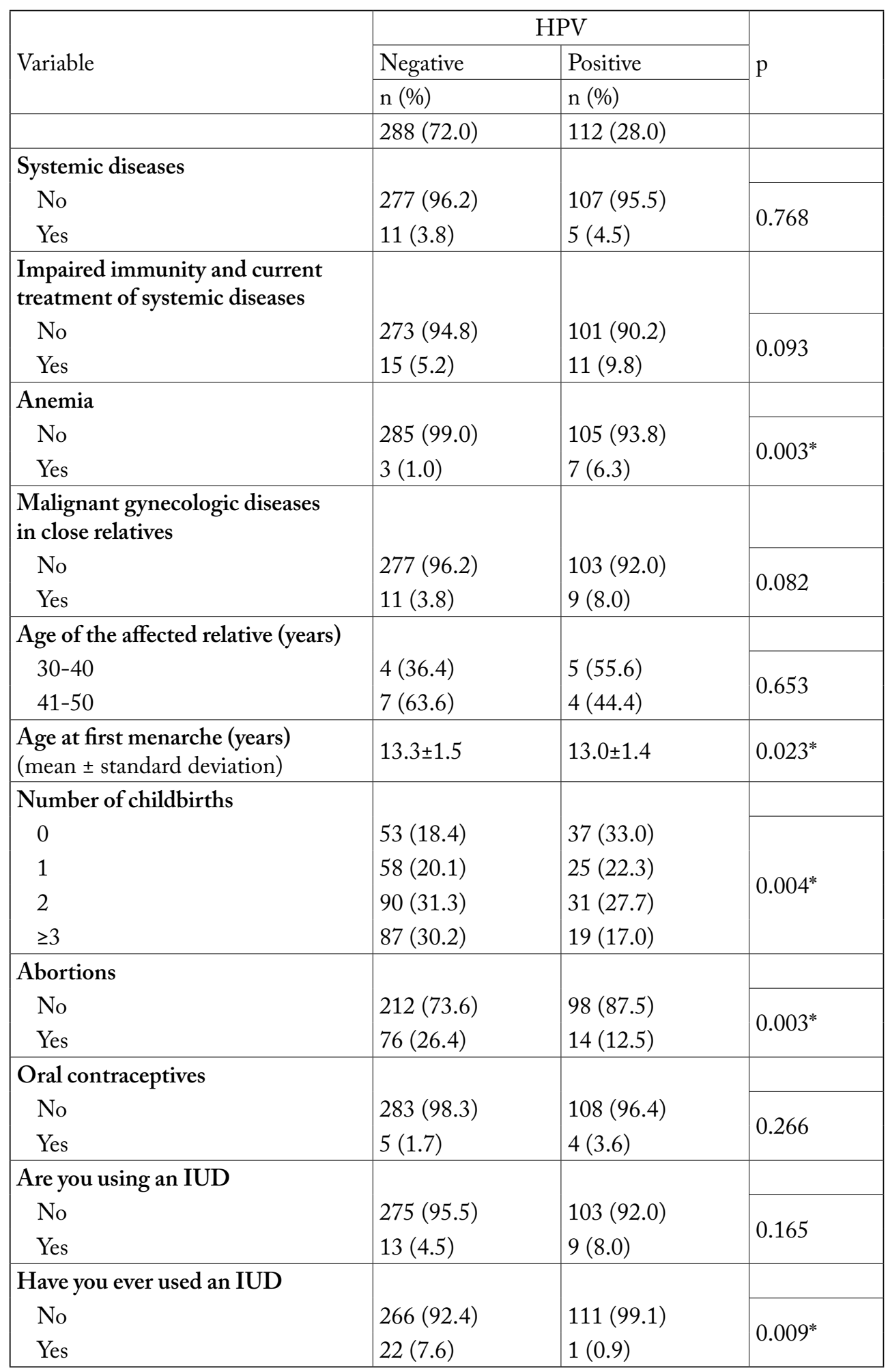

IUD $=$ intrauterine device 
Table 3. Logistic regression with human papillomavirus (HPV) status as a dependent variable

\begin{tabular}{|c|c|c|c|c|c|c|}
\hline \multirow{2}{*}{ Independent variable } & \multicolumn{3}{|c|}{ Univariate } & \multicolumn{3}{|c|}{ Multivariate } \\
\hline & B & $\mathrm{p}$ & OR (95\%CI) & $\mathrm{B}$ & $\mathrm{p}$ & OR $(95 \% \mathrm{CI})$ \\
\hline \multicolumn{4}{|l|}{ Residence } & \multirow{4}{*}{$\begin{array}{l}1.59 \\
0.69\end{array}$} & \multirow{4}{*}{$\begin{array}{l}<0.001 \\
0.021\end{array}$} & \multirow{4}{*}{$\begin{array}{l}4.9(2.8-8.6) \\
2.0(1.1-3.6)\end{array}$} \\
\hline Northern region & \multicolumn{3}{|c|}{ Reference category } & & & \\
\hline Central region & 1.13 & 0.002 & $3.1(1.5-6.3)$ & & & \\
\hline Southern region & 0.46 & 0.214 & $1.6(0.8-3.2)$ & & & \\
\hline \multicolumn{4}{|l|}{ Living conditions } & & & \\
\hline Good & \multicolumn{3}{|c|}{ Reference category } & & & \\
\hline Very good & 0.59 & 0.111 & $1.8(0.9-3.7)$ & & & \\
\hline Excellent & 0.13 & 0.713 & $1.1(0.6-2.2)$ & & & \\
\hline Smoker & 0.25 & 0.321 & $1.3(0.8-2.1)$ & & & \\
\hline \multicolumn{4}{|l|}{$\begin{array}{l}\text { Age at first sexual } \\
\text { intercourse (years) }\end{array}$} & & & \\
\hline$<16$ & \multicolumn{3}{|c|}{ Reference category } & & & \\
\hline $16-20$ & -0.09 & 0.819 & $0.9(0.4-2.0)$ & & & \\
\hline $21-24$ & -0.49 & 0.276 & $0.6(0.3-1.5)$ & & & \\
\hline$>25$ & -1.01 & 0.108 & $0.4(0.1-1.2)$ & & & \\
\hline With permanent partner & -1.97 & 0.921 & $1.0(0.5-1.8)$ & & & \\
\hline Anemia & 1.91 & 0.012 & $6.7(1.5-29.9)$ & 1.98 & 0.009 & $7.3(1.6-32.0)$ \\
\hline First menarche & -0.22 & 0.017 & $0.8(0.7-1.0)$ & -0.22 & 0.010 & $0.8(0.7-0.9)$ \\
\hline \multicolumn{4}{|l|}{ Number of childbirths } & & & \\
\hline 0 & \multicolumn{3}{|c|}{ Reference category } & & & \\
\hline 1 & -0.23 & 0.508 & $0.8(0.4-1.6)$ & & & \\
\hline 2 & -0.10 & 0.781 & $0.9(0.5-1.8)$ & & & \\
\hline$\geq 3$ & -0.13 & 0.756 & $0.9(0.4-1.9)$ & & & \\
\hline Abortion & -0.69 & 0.043 & $0.5(0.3-1.0)$ & -0.79 & 0.018 & $0.5(0.2-0.9)$ \\
\hline IUDs used in the past & 0.13 & 0.184 & $0.2(0.03-2.0)$ & & & \\
\hline
\end{tabular}

IUD = intrauterine device

region $(\mathrm{B}=1.59 ; \mathrm{p}<0.001)$ and southern region $(\mathrm{B}=0.69$, $\mathrm{p}=0.021)$ compared to the northern region taken as a reference category] and anemia $(B=1.98, \mathrm{p}=0.012)$, while menarche $(\mathrm{B}=-0.22 ; \mathrm{p}=0.010)$ and abortion $(\mathrm{B}=-$ $0.79 ; \mathrm{p}=0.018)$ were associated with reduction in the risk of $\mathrm{HPV}$ infection.

\section{Discussion}

Just over a quarter of subjects had a positive HPV finding. Positive HPV genotypes 33, 35, 39 were statistically significantly more frequent in Podgorica compared to other places of residence $\left(\chi^{2}\right.$-test $=26.455$, $\mathrm{p}<0.001)$, in women with very good living conditions $\left(\chi^{2}\right.$-test $\left.=12.264, \mathrm{p}<0.001\right)$, in women who smoked cigarettes $\left(\chi^{2}\right.$-test $\left.=5.074, \mathrm{p}=0.024\right)$, in women who had their first sexual intercourse between the ages of 17 and $20\left(\chi^{2}\right.$-test $\left.=5.874, \mathrm{p}=0.015\right)$, and in women without permanent partners $\left(\chi^{2}\right.$-test $\left.=6.061, \mathrm{p}=0.014\right)$.

Diagnostic screening for HPV lesions is generally available in the developed world but scarce everywhere else for the lack of public health policy, professional and general education, media awareness, clinical settings, financial resources and, most crucially, insufficient capacity for effective follow-up treatment of identified lesions. Screening is typically visual and subjective, with which even the most highly trained experts sometimes are unable to agree. New tests for molecular biomarkers 
of infection and disease have greatly improved the sensitivity and reliability, and are beginning to help define the degree of present and future risk ${ }^{4}$.

About $80 \%$ of cases of cervical cancer occur in developing countries, mainly in Central America, Africa south of the Sahara and Melanesia ${ }^{5}$. In these regions, cervical cancer is one of the leading causes of death in women and causes around 190,000 deaths a year ${ }^{6}$.

As regards the socio-demographic characteristics and sexual behavior of subjects, we determined that the length of smoking habit $\left(\chi^{2}\right.$-test $\left.=0.638, p=0.424\right)$ and protected sexual intercourse $\left(\chi^{2}\right.$-test $=2.628, \mathrm{p}=$ $0.105)$ were not significant variables affecting the HPV status.

Tobacco use is also a known risk factor for cervical cancer ${ }^{7}$. Direct carcinogenic effect of cigarette smoking on the cervix is supported by the fact that nicotine metabolites can be found in cervical mucus of women smokers ${ }^{8}$. Women who smoke 15 and more cigarettes a day are at twice as high risk of HPV infection compared to non-smokers. The risk is at its highest in women between the ages of 45 and 50, while about $37 \%$ of women developing HPV infection are under the age of 35 . Women older than 65 make up $10 \%$ of patients $^{9-11}$.

Patients with HPV-positive oropharyngeal carcinoma (OPC) had higher income and education level than patients with HPV-negative OPC, and among patients with $\mathrm{HPV}$-positive OPC, never/light smokers had the highest income and education levels. Sexual exposures were more common among patients with HPV-positive tumors, particularly smokers with $\mathrm{HPV}$-positive tumors, and sexual exposures were more common among patients with higher education level and socioeconomic status ${ }^{12}$.

The gynecologic characteristics and associated diseases that did not significantly affect the HPV status according to our study were systemic diseases $\left(\chi^{2}\right.$-test= $0.087, \mathrm{p}=0.768)$, impaired immunity and current treatment of systemic diseases $\left(\chi^{2}\right.$-test $\left.=2.824, p=0.093\right)$, malignant gynecologic diseases in close relatives $\left(\chi^{2}\right.$-test= 3.018, $\mathrm{p}=0.082)$, age of the affected relative $(\mathrm{p}=0.653)$, use of oral contraceptives $\left(\chi^{2}\right.$-test $\left.=1.235, \mathrm{p}=0.266\right)$, and current usage of IUDs $\left(\chi^{2}\right.$-test $\left.=1.924, p=0.165\right)$.

Generally, there is a high prevalence of HPV infection in younger population throughout Europe $^{13}$, including our country, which can heavily be influenced by early initiation of sexual intercourse among young peo- ple of European countries (over 78\% of them have their first sexual intercourse before the age of 18$)^{9,14}$. In the last thirty years, epidemiological studies have shown that sexual behavior has an impact on the risk of cervical cancer, e.g., number of partners, age at first sexual intercourse and partner's sexual behavior ${ }^{15,16}$.

The gynecologic characteristics and associated diseases that significantly affected the HPV status were the presence of anemia $\left(\chi^{2}\right.$-test $\left.=8.974, p=0.003\right)$, number of childbirths $\left(\chi^{2}\right.$-test $\left.=13.537, \mathrm{p}=0.004\right)$, menarche $(\mathrm{t}=2.283, \mathrm{p}=0.023)$, abortion $\left(\chi^{2}\right.$-test $\left.=8.921, \mathrm{p}=0.003\right)$, and usage of IUDs $\left(\chi^{2}\right.$-test $\left.=6.772, \mathrm{p}=0.009\right)$.

In the group of women who were HPV positive, significantly more frequent were women with anemia $\left(\chi^{2}\right.$-test $\left.=8.974, p=0.003\right)$, nulliparous women $\left(\chi^{2}\right.$-test $=$ 9.902, $\mathrm{p}=0.002)$, women with early menarche $(\mathrm{t}=2.283$, $\mathrm{p}=0.023)$, women who did not have abortions $\left(\chi^{2}-\right.$ test=8.921, $\mathrm{p}=0.003)$, and women who never used IUDs $\left(\chi^{2}\right.$-test $\left.=6.772, \mathrm{p}=0.009\right)$.

Systemic diseases and immune system impairment certainly contribute to the development of cervical cancer, particularly if it is combined with one or more cofactors, e.g., viral infection or bacterial vaginosis. Studies have shown that bacterial vaginosis is statistically significantly more frequent in subjects with cervical precancerous lesions or cervical cancer than in healthy women ${ }^{17}$.

Patients suffering from chronic infections or inflammatory diseases usually develop normocytic normochromic anemia, followed by characteristic hypoferremia. This usually moderate anemia is caused by a reduced production of red blood cells (RBC) in combination with a slight decrease in RBC life $\operatorname{span}^{18}$. Based on the interaction among iron, immunity and infection, anemia is considered to have a highly undesirable effect. The RBC production has evolved to become very sensitive to reduced iron availability, regardless of whether it is a real iron deficiency or an inflammatory iron restriction. The inhibition of erythropoiesis by hypoferremia preserves iron for other metabolic uses during infection, and can facilitate diversion of bone marrow protectors towards the production of leukocytes for host defense. Experimental evidence suggests that erythropoiesis is uniquely sensitive to hypoferremia ${ }^{19}$ and that other tissues can use iron even when it is available at much lower concentrations than normal. Because of the relatively long RBC life span (4 months), it takes several weeks for anemia to develop, 
unless there is a significantly increased RBC destruction or blood loss, which can be seen in rapidly evolving anemia accompanying infectious diseases. Hypoferremia is not the only consequence of inflammation that limits erythropoiesis. Inflammatory cytokines directly suppress erythropoiesis, likely to increase the production of leukocytes, and also activate macrophages for increased erythrophagocytosis ${ }^{20}$.

It has been proven that female partners of patients that developed cancer on one of the reproductive organs have an increased risk of developing cervical cancer ${ }^{21}$.

The age of the relatives who were cancer patients had no statistical significance since the frequency was very low.

The number of successful deliveries is also a very important factor in developing countries, where examinations are not readily available. It is considered that the higher the number of childbirths, the higher is the risk of cervical cancer. Research that supports this claim was carried out in Central and South America ${ }^{22}$.

We should also point out the significance of the vaccines produced to fight and reduce the incidence of cervical cancer. Two vaccines that prevent infection with HPV types 16 and 18 have been approved by the European Medicines Agency but, in our country, they are applied selectively, so there are no statistical data on their usage. Successful Pap tests have reduced the incidence of cervical cancer in developed countries by $50 \%{ }^{23}$. During 2017, the Institute of Public Health in coordination with the Departments of Gynecology and Pediatrics established a Working Group that strives towards the adoption of the Act on Compulsory HPV Vaccination of children aged 9 to 14, the implementation of which is planned to be finished by the end of 2019.

There is high-reliable evidence that HPV vaccines protect against cervical pre-cancer in adolescent girls and women who are vaccinated between 15 and 26 years of age. The protection is lower when a part of the population is already infected with HPV. Longer follow-up is needed to assess the impact on cervical cancer. The vaccines do not increase the risk of serious adverse events, miscarriage or pregnancy termination. There are limited data from trials on the effect of vaccines on deaths, stillbirth and babies born with malformations ${ }^{24}$.

Clarification of the molecular mechanism underlying HPV persistence and related cervical cancer will help predict the prognosis of patients with HPV infections at an earlier stage. Molecular classification based on HPV integration and genetic profiling may also translate into the precision medicine that allows clinicians to focus medical resources more on high-risk patients whose diseases are genuinely progressing, greatly reducing the psychological and economic burdens of the cervical screening programs and HPV vaccination programs in the future ${ }^{25}$.

\section{Conclusion}

By implementing the screening program and HPV typing, we came to the conclusion that the problem of cervical cancer could be solved or at least mitigated by raising awareness of the causes and incidence of cervical cancer, as well as by being well informed on its curability, predictability and protection during intercourse, which would contribute to positive changes.

\section{References}

1. Vukićević D, Mitić R, Mijović M, Mitić N, Vitković L, Đerković B, Nedeljković V. Deskriptivno-epidemiološke karakteristike karcinoma grlića materica. Praxis Medica. 2015; 44(1):67-72.

2. Colaković B, Colaković-Popović V. Incidence of cervical cancer in Montenegro. Clin Exp Obstet Gynecol. 2008;35(4):275-8.

3. Control of cancer of the cervix uteri. A WHO meeting. Bull World Health Organ. 1986;64(4):607-18.

4. Bosch FX, Broker TR, Forman D, et al. Comprehensive control of human papillomavirus infections and related diseases. Vaccine. 2013;31 Suppl 8(08):I1-I31. doi: 10.1016/j.vaccine.2013. 07.026

5. Parkin M. International Agency for Research on Cancer (personal communication). July 2000.

6. Pisani P, Parkin DM, Bray F, Ferlay J. Estimates of the worldwide mortality from 25 cancers in 1990. Int J Cancer. $1999 \mathrm{Sep}$ 24;83(1):18-29.

7. Winkelstein W. Smoking and cervical cancer: current status - a review Am J Epidemiol. 1990;131:45-57.

8. Schiffman MH, Haley NJ, Felton JS, Andrews AW, Kaslow RA, Lancaster WD. Biochemical epidemiology of cervical neoplasia: measuring cigarette smoke constituents in the cervix. Cancer Res. 1987;47:3886-8.

9. Kjellberg L, Hallmans G, Ahren A-M, Johansson R, Bergman F, Wadell G, Angstrom T, Dillner J. Smoking, diet, pregnancy and oral contraceptive use as risk factors for cervical intra-epithelial neoplasia in relation to human papillomavirus infection. Br J Cancer. 2000;82(7):1332-8. 
10. Jensen KE, Thomsen LT, Schmiedel S. Chlamydia trachomatis and risk of cervical intraepithelial neoplasia grade 3 or worse in women with persistent human papillomavirus infection: a cohort study. Sex Transm Infect. 2014;90(7):550-5. doi: 10.1136/ sextrans-2013-051431

11. https://www.cancer.org/cancer/cervical-cancer/causes-risksprevention/risk-factors.html

12. Dahlstrom KR, Bell D, Hanby D, et al. Socioeconomic characteristics of patients with oropharyngeal carcinoma according to tumor HPV status, patient smoking status, and sexual behavior. Oral Oncol. 2015;51(9):832-8. doi: 10.1016/j.oraloncology.2015.06.005

13. Arbyn M, Anttila A, Jordan J, Ronco G, Schenck U, Segnan N, Wiener A, Herbert A, von Karsa L. European guidelines for quality assurance in cervical cancer screening. Brussels, Luxembourg: European Community, Office for Official Publicationas of the European Communities, 2008.

14. Gierisch JM, Coeytaux RR, Urrutia RP. Oral contraceptive use and risk of breast, cervical, colorectal, and endometrial cancers: a systematic review. Cancer Epidemiol Biomarkers Prev. 2013;22(11):1931-43.

15. Schiffman MH, Haley NJ, Felton JS, Andrews AW, Kaslow RA, Lancaster WD. Biochemical epidemiology of cervical neoplasia: measuring cigarette smoke constituents in the cervix. Cancer Res. 1987;47:3886-8.

16. Franco EL. Epidemiology of uterine cancers. In: Meisels A, Morin C, editors. Cytopathology of the Uterus. $2^{\text {nd }}$ edn. Chicago: American Society of Clinical Pathologists, 1997; p. 301-24.

17. Vaccarella S, Lortet-Tieulent J, Plummer M, Franceschi S, Bray F. Worldwide trends in cervical cancer incidence: impact of screening against changes in disease risk factors. Eur J Cancer. 2013 Oct;49(15):3262-73. doi: 10.1016/j.ejca.2013.04.024

18. Cartwright GE, Lee GR. The anaemia of chronic disorders. $\mathrm{Br}$ J Haematol. 1971;21:147-52.

19. Bullock GC, Delehanty LL, Talbot AL, et al. Iron control of erythroid development by a novel aconitase-associated regulatory pathway. Blood. 2010;116(1):97-108. doi: 10.1182/blood $-2009-10-251496$

20. Libregts SF, Gutierrez L, de Bruin AM. Chronic IFN-gamma production in mice induces anemia by reducing erythrocyte life span and inhibiting erythropoiesis through an IRF-1/PU.1 axis. Blood. 2011;118:2578-88.

21. Graham S, Priore R, Graham M, Browne R, Burnett W, West D. Genital cancer in wives of penile cancer patients. Cancer. 1979;44:1870-4.

22. Brinton LA, Hamman RF, Huggins GR, Lehman HF, Levine $\mathrm{RS}$, Mallin K, et al. Sexual and reproductive risk factors for invasive squamous cell cervical cancer. J Natl Cancer Inst. 1987;79:23-30.

23. Mosiur Rahman, Abdur R Mia, Syed Emdadul Haque, Mostofa Golam, Nowsheen Sharmin Purabi, Choudhury SAR. Beating cervical cancer in the developed countries: a dream or reality? In: Alfonso J. Rodriguez-Morales. Current Topics in Public Health. IntechOpen, 2013; p. 341-58. doi: 10.5772/52881.

24. Arbyn M, Xu L, Simoens C, Martin-Hirsch PP. Prophylactic vaccination against human papillomaviruses to prevent cervical cancer and its precursors. Cochrane Database Syst Rev. 2018; 5(5):CD009069. doi: 10.1002/14651858.CD009069.pub3

25. $\mathrm{Hu} \mathrm{Z}, \mathrm{Ma} \mathrm{D}$. The precision prevention and therapy of HPVrelated cervical cancer: new concepts and clinical implications. Cancer Med. 2018;7(10):5217-36. doi: 10.1002/cam4.1501 


\title{
Sažetak \\ HPV TIPIZACIJA KAO PROGRAM PROBIRA ZA PREVENCIJU I RANO OTKRIVANJE RAKA GRLIĆA MATERNICE U RAZLIČITIM CRNOGORSKIM REGIJAMA
}

\author{
A. Lukač, N. Šulović, S. Smiljič, A. N. Ilicí i M. Šašić
}

Cilj našega istraživanja bio je usporediti rezultate tipizacije humanog papilomavirusa (HPV) i zastupljenosti najvažnijih čimbenika rizika za oboljele od raka grlića maternice između gradova sjevernog, centralnog i južnog područja Crne Gore u populaciji žena u dobi od 30-35 godina, predviđene novim programom probira koji je Ministarstvo zdravlja Crne Gore uvelo 2018. godine. Studijom su obuhvaćene bolesnice iz Rožaja, Berana, Budve i Podgorice, ukupno njih 400 (po 100 iz svakog grada) kod kojih je provedena HPV tipizacija predviđena najnovijim programom probira za rano otkrivanje i prevenciju raka grlića maternice Ministarstva zdravlja Crne Gore u 2018. godini. Materijal je uzorkovan u ambulantama Domova zdravlja u Rožajama, Beranama, Podgorici i Budvi. Specijalnim četkicama se uzima bris s grlića maternice, a zatim uzorkuje u posebnoj epruveti s podlogom i šalje na analizu u Institut za javno zdravlje Crne Gore gdje se radi HPV tipizacija metodom RT-PCR (real-time polymerase chain reaction). Rezultati su se dobivali elektronički i šifrirani. Svim ispitanicama su se uzeli i analizirali podaci iz anketnog upitnika koji je sastavljen kao dio ovoga programa, a ispitanice su dobrovoljno pristale na program probira. Gotovo jedna četvrtina ispitanica je imala pozitivan nalaz HPV.U skupini žena pozitivnih na HPV bilo je značajno više žena iz Podgorice $\left(\chi^{2}\right.$-test $\left.=26,455, p<0,001\right)$, žena koje imaju vrlo dobre uvjete života $\left(\chi^{2}\right.$-test $\left.=12,264, p<0,001\right)$, žena koje puše cigarete $\left(\chi^{2}\right.$-test $\left.=5,074, p=0,024\right)$, žena koje su imale prvi seksualni odnos u dobi od 17-20 godina $\left(\chi^{2}\right.$-test $=5,874$, $\mathrm{p}=0,015)$ i žena koje nemaju stalne partnere $\left(\chi^{2}\right.$-test $\left.=6,061, \mathrm{p}=0,014\right)$. Promatrajući sociodemografske karakteristike i seksualno ponašanje ispitanica prema HPV statusu kao varijable koje nisu pokazale značajnost izdvojile su se pušački staž $\left(\chi^{2}-\right.$ test $=0,638, p=0,424)$ i žaštićen seksualni odnos $\left(\chi^{2}\right.$-test $\left.=2,628, p=0,105\right)$. Provođenjem programa probira i HPV tipizacije dolazimo do zaključka da bi se problem mogao riješiti ili barem ublažiti podizanjem svijesti o uzrocima i učestalosti raka grlića maternice kao i informiranosti o izlječivosti, predvidljivosti i seksualnoj zaštiti, što bi doprinijelo pozitivnim promjenama.

Ključne riječi: HPV infekcija; Čimbenici rizika; Karcinom grlica maternice 